\title{
ANALISIS PERSEPSI USAHA MIKRO TERHADAP PEMANFAATAN MEDIA DARING DI KOTA SAMARINDA
}

\section{(ANALYSIS OF MICRO BUSINESS PERCEPTION ON THE USE OF ONLINE MEDIA IN SAMARINDA CITY)}

\author{
Bramantyo Adi Nugroho, Puput Wahyu Budiman, Noor Wahyuningsih \\ Badan Penelitian dan Pengembangan Daerah Provinsi Kalimantan Timur \\ Jalan M.T. Haryono No. 126 Rawa Indah Samarinda \\ Email: bramantyo@kaltimprov.go.id
}

Diterima: 13 Juni 2019; Direvisi: 24 Juni 2019; Disetujui: 26 Juni 2019

\begin{abstract}
ABSTRAK
Tujuan dari kajian ini adalah untuk mengetahui persepsi pelaku usaha mikro terhadap pemanfaatan media sosial dalam mendukung kinerja usaha di Kota Samarinda. Metode pengumpulan data pada penelitian ini dilakukan dengan kuesioner dan wawancara serta observasi secara langsung di lokasi responden dan dengan cara studi literatur seperti jurnal, artikel, hasil riset, buku dan arsip dari masing-masing kecamatan, Dinas UMKM Kota Samarinda. Penelitian ini berfokus hanya pada persepsi pelaku usaha mikro yang bergerak dalam bidang jasa, bidang dagang dan bidang manufaktur. Penelitian ini dilakukan di 10 (sepuluh) kecamatan yang ada di Samarinda yaitu Kecamatan Samarinda Kota, Kecamatan Samarinda Ilir, Kecamatan Samarinda Seberang, Kecamatan Samarinda Ulu, Kecamatan Samarinda Utara, Kecamatan Loa Janan Ilir, Kecamatan Palaran, Kecamatan Sambutan, Kecamatan Sungai Kunjang dan Kecamatan Sungai Pinang. dengan sampel penelitian sebanyak 100 buah. Jumlah sampel didapat dengan perhitungan rumus Slovin. Adapun Kesimpulan Kajian Analisis Persepsi Usaha Mikro Terhadap Pemanfaatan Media Daring Di Kota Samarinda adalah (1) Masih terbatasnya pemanfaatan media daring pada pelaku Usaha Mikro baik dilihat dari penggunaan komputer ataupun handphone maupun internet dalam pengelolaan usahanya. (2) Beberapa faktor-faktor kunci penghambat yang menentukan tingkat pemanfaatan media daring pada pelaku Usaha Mikro di Kota Samarinda ini yaitu (a) Rendahnya pemahaman terhadap manfaat teknologi informasi terutama media daring dalam pengembangan usaha; (b) Rendahnya ketersediaan investasi teknologi informasi; (c) Masih rendahnya dukungan lembaga pemerintah. (3) Sedangkan beberapa faktor-faktor kunci pendukung yang menentukan tingkat pemanfaatan teknologi informasi pada pelaku Usaha Mikro di Kota Samarinda ini yaitu (a) Ketersediaan sumberdaya manusia dari sisi pendidikan yang relatif baik; (b) Kemampuan individu dari pelaku usaha mikro yang relatif baik dalam informasi dan teknologi dan dalam pemanfaatan media daring (e-commerce).
\end{abstract}

Kata kunci: Usaha Mikro; Media Daring; Teknologi Informasi.

\begin{abstract}
The purpose of this study was to find out perceptions about micro-enterprises on the use of social media in supporting businesses in Samarinda City. The method of data collection in this study was conducted with questionnaires and interviews as well as direct observation at the respondent's location and by means of literature studies such as journals, articles, research results, books and archives from each Sub-District, Samarinda UMKM Service. This research only supports micro business printing that is engaged in services, trade and manufacturing. The study was conducted in 10 (repetitive) sub-districts in Samarinda, namely Samarinda Kota Sub-District, Samarinda Ilir Sub-District, Samarinda Seberang Sub-District, Samarinda Ulu District, North Samarinda SubDistrict, Loa Janan Ilir Sub-District, Palaran District, Sambutan District, Sungai Kunjang District
\end{abstract}


and District Sungai Pinang. with a sample of 100 pieces. The number of samples is obtained by calculating the Slovin formula. Based on the conclusions of the Micro Business Perception Analysis Study on the Use of Online Media in Samarinda City are (1) The limited use of online media on the dangers of Micro-Business both from the use of computers and cellphones and the internet in managing their businesses. (2) Some key inhibiting factors that determine the level of utilization of online media in the efforts of Micro Enterprises in Samarinda City are (a) Low understanding of the benefits of information technology requires online media in business development; (b) Information technology investment is low; (c) Still low support from government institutions. (3) While some of the key supporting factors that determine the level of development of information technology in Micro businesses in Samarinda City are (a) Development of human resources in terms of education that is relatively good; (B) Individual abilities of micro businesses that are relatively good in information and technology and in the use of online media (e-commerce).

Keywords: Micro business; Online media; Information Technology.

\section{PENDAHULUAN}

UMKM (Usaha Mikro, Kecil, dan Menengah) merupakan kegiatan usaha yang mampu memperluas lapangan pekerjaan dan memberikan pelayanan ekonomi secara luas kepada masyarakat dan sekaligus dapat berperan dalam proses pemerataan dan peningkatan pendapatan masyarakat, pendorong pertumbuhan ekonomi, dan berperan dalam mewujudkan stabilitas nasional. Selain itu, UMKM adalah salah satu pilar utama ekonomi nasional yang harus memperoleh penempatan utama, dukungan, perlindungan dan pengembangan yang seluasluasnya sebagai wujud keberpihakan yang tegas kepada kelompok usaha ekonomi rakyat, tanpa mengabaikan peranan Usaha Besar dan Badan Usaha Milik Negara (BUMN) (Hariati, Ikhsan, \& Nur, 2018).

Di dalam era globalisasi ini dan dengan adanya revolusi industri 4.0 maka, UMKM di Indonesia merupakan salah satu sektor yang terdampak. Sebagai salah satu penopang ekonomi negara yang dapat bertahan dari krisis ekonomi maka sudah selayaknya UMKM mendapat dukungan terutama dari pemerintah dan tentu saja dari sektor-sektor yang lain.

Pemerintah telah berupaya meningkatkan akses dan transfer teknologi untuk mengembangkan pelaku UMKM antara lain dengan pemanfaatan teknologi informasi sehingga diharapkan akan mampu bersaing dengan pelaku UMKM asing. Saat ini, pemasaran produk dan pelayanan perusahaan merupakan proses yang interaktif akibat penggunaan teknologi informasi. Perusahaan tidak hanya menyediakan katalog produk dan promosi di situsnya, namun situs perusahaan sudah digunakan sebagai sarana untuk berdialog, berdiskusi, dan berkonsultasi dengan konsumen secara daring, menampilkan bulletin boards, membuat kuesioner elektronik, mailing list, dan koordinasi melalui surat elektronik (Rustono, 2013 dalam Slamet et al., 2016).

Pemberdayaan dan pengembangan UMKM merupakan upaya yang ditempuh pemerintah Indonesia untuk mengatasi masalah pengangguran dan kemiskinan. UMKM di negara berkembang, seperti di Indonesia, sering dikaitkan dengan masalah- masalah ekonomi dan sosial dalam negeri seperti tingginya tingkat kemiskinan, besarnya jumlah pengangguran, ketimpangan distribusi pendapatan, proses pembangunan yang tidak merata antara daerah perkotaan dan perdesaan, serta masalah urbanisasi (Setiawati, Novandalinda, \& Prihatiningsih, 2017).

Undang-undang No.20 Tahun 2008 tentang Usaha Mikro, Kecil, Menengah menyatakan bahwa UMKM merupakan kegiatan usaha yang mampu memperluas lapangan pekerjaan dan memberikan pelayanan ekonomi secara luas kepada masyarakat dan dapat berperan dalam proses pemerataan dan peningkatan pendapatan masyarakat, guna mendorong pertumbuhan ekonomi dan berperan dalam mewujudkan stabilitas nasional.

Dunia bisnis sebagai induk dari pemasaran terus-menerus berubah menyesuaikan diri dengan kemajuan zaman. Perubahan dalam dunia pemasaran atau marketing merupakan suatu 
keharusan, seperti halnya dengan ilmu pengetahuan, bersifat dinamis dan selalu mengalami perubahan. Keberadaan teknologi yang semakin canggih, memperluas proses pemasaran dalam transaksi bisnis dengan menggunakan jaringan internet. Dalam era seperti saat ini, telah terjadi pergeseran paradigma pemasaran, dari pemasaran tradisional (offline) ke pemasaran modern (online).

Transaksi bisnis melalui internet merupakan satu fenomena bisnis baru. Salah satu manfaat internet sebagai sarana memperkenalkan dan memasarkan produk barang atau jasa. Dari sisi finansial, pemasaran daring sangat menjanjikan untuk peningkatan laba usaha. Pemberdayaan dan pengembangan UMKM merupakan upaya yang ditempuh pemerintah Indonesia untuk mengatasi masalah pengangguran dan kemiskinan (Setiawati \& Widyartati, 2017).

Penggunaan internet sebagai sarana bisnis sangat berkembang cepat di era informasi dan jejaring. Hal ini terlihat dengan maraknya kemunculan berbagai bisnis daring yang menawarkan aneka produk dan jasa yang tak terbatas baik untuk memenuhi segala kebutuhan sehari-hari maupun kebutuhan khusus. Online Buying Akan Menjadi Masa Depan Pemasaran. Pelaku bisnis dan praktisi pemasaran produk kreatif mempunyai keyakinan bahwa pemasaran produk akan sangat bergantung kepada daring, dikarenakan sebagian besar konsumen mereka merupakan early adopter ataupun follower atas teknologi komunikasi. Disamping itu penetrasi pemasaran ke berbagai daerah di Indonesia bahkan internasional bukan menjadi kendala seperti dalam pemasaran konvensional (Pangarso, Fajar Firdaus, \& K. Moeliono, 2016).

Media Daring atau e-commerce merupakan proses pembelian, penjualan, transfer atau pertukaran barang, jasa dan atau informasi melalui jaringan komputer, termasuk internet (Turban, 2009). E-commerce memiliki beberapa bentuk tergantung pada tingkat digitalisasi (transformasi dari fisik ke digital) dari (1) barang/jasa yang dijual, (2) proses (misal pemesanan, pembayaran, pemenuhan/penyelesaian), dan (3) metode pengiriman. Barang bisa berupa fisik atau digital, proses bisa berupa fisik atau digital, demikian juga metode pengiriman bisa berupa fisik maupun digital. Perdagangan tradisional memiliki tiga dimensi yang bersifat fisik, sedangkan pada pure e-commerce memiliki tiga dimensi yang bersifat digital. Jika salah satu dimensi bersifat digital maka disebut partial e-commerce (Turban, 2009). E-commerce memberikan keuntungan bagi perusahaan dalam peningkatan efisiensi, pengurangan biaya inventori, peningkatan penjualan, peningkatan relasi dengan konsumen, penetrasi pasar baru, dan pada akhirnya financial returns. E-commerce menyediakan biaya yang efektif bagi UKM untuk memasarkan sendiri, launching produk baru, meningkatkan komunikasi, mendapatkan informasi dan mengidentifikasi partner bisnis yang potensial dan mampu berkompetisi (Bao dan Sun, 2010).

Munculnya media daring dibarengi dengan berkembangnya industri mobile phone yang semakin pesat dapat mempermudah mengakses berbagai informasi untuk dilakukan dimana dan kapan saja hanya dengan menggunakan sebuah mobile phone. Demikian cepatnya orang bisa mengakses media daring mengakibatkan terjadinya fenomena besar terhadap arus informasi tidak hanya di negara maju, tetapi juga di negara berkembang seperti di Indonesia. Kecepatan media daring melalui jaringan yang dihubungan dengan internet, juga mulai tampak menggantikan peranan media massa konvensional dalam menyebarkan berita atau berbagai informasi.

Transaksi bisnis melalui internet terutama menggunakan media daring, merupakan satu fenomena bisnis baru. Salah satu bentuk teknologi informasi yang dapat diterapkan oleh UMKM untuk mengembangkan usahanya adalah dengan mengadopsi e-commerce. Biaya, kecepatan, dan kapasitas penanganan data menentukan keuntungan dari internet dan nilai untuk e-commerce. Teknologi internet memungkinkan perusahaan untuk melakukan bisnis di daerah geografis dengan kecepatan tinggi, fleksibilitas, dan ekonomis (Ningtyas, Sunarko, \& Jaryono, 2015). Kemunculan berbagai media daring atau yang sering disebut e-commerce telah 
memberikan warna tersendiri pada transaksi bisnis perdagangan daring, salah satunya sebagai sarana memperkenalkan dan memasarkan produk barang atau jasa.

Dari sisi finansial bisnis daring teramat sangat menjanjikan. Pemberdayaan dan pengembangan UMKM merupakan upaya yang ditempuh pemerintah Indonesia untuk mengatasi masalah pengangguran dan kemiskinan. UMKM di negara berkembang, seperti di Indonesia, sering dikaitkan dengan masalah-masalah ekonomi dan sosial dalam negeri seperti tingginya tingkat kemiskinan, besarnya jumlah pengangguran, ketimpangan distribusi pendapatan, proses pembangunan yang tidak merata antara daerah perkotaan dan perdesaan, serta masalah urbanisasi.

UMKM diharapkan menjadi salah satu upaya mengembangkan wirausaha baru sebagai usaha ekonomi produktif yang berdiri sendiri dan dilakukan oleh orang perorang atau badan usaha. Peran penting UMKM dalam menciptakan pasar baru dan sumber inovasi dituntut untuk melakukan restrukturisasi dan reorganisasi dengan tujuan untuk memenuhi permintaan konsumen yang makin spesifik, berubah dengan cepat, produk berkualitas tinggi, dan harga yang murah.

Realita menunjukan bahwa, kebanyakan UMKM di Indonesia, memiliki beberapa permasalahan yang sama, salah satunya adalah kurangnya pengetahuan tentang pemasaran, disebabkan oleh terbatasnya informasi yang dapat dijangkau oleh UMKM mengenai pasar. Berdasarkan teori maupun fakta, temuan-temuan dilapangan, maka perlu dilakukan kajian lebih lanjut dengan melakukan penelitian yang bertujuan untuk memberikan suatu analisis mengenai Analisis Persepsi Usaha Mikro Terhadap Pemanfaatan Media Daring Di Kota Samarinda.

Berdasarkan hal tersebut, masalah yang akan diuji dalam kajian ini dapat dirumuskan dalam bentuk pertanyaan bagaimana persepsi pelaku usaha mikro terhadap pemanfaatan media daring dalam mendukung kinerja usaha di Kota Samarinda. Adapun tujuan dari kajian ini adalah untuk mengetahui persepsi pelaku usaha mikro terhadap pemanfaatan media sosial dalam mendukung kinerja usaha di Kota Samarinda.

\section{METODE}

Metode pengumpulan data pada penelitian ini dilakukan dengan kuesioner dan wawancara serta observasi secara langsung di lokasi responden dan dengan cara studi literatur seperti jurnal, artikel, hasil riset, buku dan arsip dari masing-masing Kecamatan, Dinas UMKM Kota Samarinda. Penelitian ini berfokus hanya pada persepsi pelaku usaha mikro yang bergerak dalam bidang jasa, bidang dagang dan bidang manufaktur.

Penelitian ini dilakukan di 10 (sepuluh) kecamatan yang ada di Samarinda yaitu Kecamatan Samarinda Kota, Kecamatan Samarinda Ilir, Kecamatan Samarinda Seberang, Kecamatan Samarinda Ulu, Kecamatan Samarinda Utara, Kecamatan Loa Janan Ilir, Kecamatan Palaran, Kecamatan Sambutan, Kecamatan Sungai Kunjang dan Kecamatan Sungai Pinang. dengan sampel penelitian sebanyak 100 buah. Jumlah sampel didapat dengan perhitungan rumus Slovin (Amirin (2011), yaitu

$$
n=\frac{N}{1+N(e)^{2}}
$$

Keterangan:

$\mathrm{n}=$ jumlah sampel

$\mathrm{N}=$ jumlah populasi

$\mathrm{e}=$ margin error "tingkat kesalahan"

Tingkat kesalahan yang diambil pada penelitian ini sebesar 10\%, maka jumlah sampel yang bisa diambil sebesar : 


$$
\begin{aligned}
& n=\frac{6.133}{1+6.133(0,1)^{2}} \\
& n=98,40 \\
& n \approx 100 \text { jiwa }
\end{aligned}
$$

Sementera itu, penentuan jumlah proporsi sampel pada setiap klaster yang digunakan dalam penelitian ini diambil dari sub populasi jumlah UMKM pada masing-masing kecamatan. Sub populasi UMKM pada masing-masing kecamatan memiliki jumlah yang tidak sama. Adapun cara pengambilan sampel dengan jumlah sub populasi yang tidak sama, yaitu mencari faktor pembanding dari tiap sub populasi yang sering disebut sebagai sampel fraction $(f)$ dengan cara membandingkan jumlah elemen tiap sub populasi dengan jumlah seluruh elemen populasi sehingga didapat masing-masing sampel fraction (Umar, 1997) dengan menggunakan rumus:

$$
f i=\frac{N_{i}}{N} \mathrm{n}
$$

Keterangan :

$f i=$ sample fraction

$N_{i}=$ jumlah sub-populasi

$N=$ jumlah populasi

$N=$ jumlah sampel yang diinginkan

Data yang dikumpulkan akan dianalisis secara deskriptif kualitatif dan deskriptif kuantitatif dengan memanfaatkan berbagai peralatan statistik deskriptif dan tabel-tabel frekuensi tunggal dan tabel-tabel frekuensi silang.

\section{HASIL DAN PEMBAHASAN}

Berdasarkan pengumpulan data yang dilakukan di 10 kantor kecamatan maka didapatkan sebanyak 6.133 Izin Usaha Mikro (IUM) antara tahun 2016-2017. Jumlah sampel diperoleh dengan rumus slovin (Amirin, 2011) dengan tingkat kesalahan sebanyak 10 persen yaitu sebesar 100 sampel. Untuk menentukan jumlah sampel dari setiap kecamatan yaitu dengan mencari factor pembanding dari setiap sub populasi yang sering disebut sebagai sampel fraction $(f)$ dengan cara membandingkan jumlah elemen tiap sub populasi dengan jumlah seluruh elemen populasi sehingga didapatkan masing-masing sampel fraction. Berdasarkan perhitungan tersebut maka didapatkan jumlah sampel dari setiap kecamatan seperti pada Tabel 1.

Tabel 1. Jumlah Sampel Penelitian

\begin{tabular}{clcc}
\hline No. & Kecamatan & Jumlah IUM 2016-2017 & Sampel \\
\hline 1 & Loa Janan llir & 228 & 4 \\
2 & Palaran & 353 & 6 \\
3 & Samarinda Ilir & 526 & 9 \\
4 & Samarinda Kota & 511 & 8 \\
5 & Samarinda Seberang & 388 & 6 \\
6 & Samarinda Ulu & 1399 & 23 \\
7 & Samarinda Utara & 734 & 12 \\
8 & Sambutan & 326 & 5 \\
9 & Sungai Kunjang & 1363 & 22 \\
10 & Sungai Pinang & 305 & 5 \\
\hline & Jumlah & $\mathbf{6 1 3 3}$ & $\mathbf{1 0 0}$ \\
\hline
\end{tabular}

Sumber : Diolah dari data IUM 10 Kecamatan di Kota Samarinda (2018) 
Penentuan sampel yang menjadi responden pada penelitian ini didasarkan pada angka random yang didapatkan dari penggunaan fungsi randbetween pada Microsoft Excel.Hasil analisis statistik deskriptif selengkapnya dapat diihat dalam Tabel 2,3 dan 4.

Berdasarkan tabel 2 diketahui bahwa dari 100 sampel responden, sebanyak 43 persen adalah pria dan 57 persen sisanya adalah wanita. Jadi mayoritas responden adalah wanita. Dari tabel distribusi berdasar usia (Tabel 3), usia 41-50 tahun merupakan usia sampel responden terbanyak yaitu sebesar 35 responden ( 35 persen). Hanya ada 1 responden (1 persen) yang berusia dibawah 20 tahun. Berdasarkan pendidikan terakhir (Tabel 4), responden yang terbanyak adalah responden yang mempunyai Pendidikan terakhir SMA/SMK yaitu sebanyak 59 responden atau dengan presentase sebesar 59 persen. Sedangkan responden dengan Pendidikan D3 adalah yang paling sedikit yaitu hanya 1 (satu) orang.

Tabel 2. Distribusi Responden Berdasar Gender

\begin{tabular}{ccc}
\hline Jenis Kelamin & Frekuensi & Persentase (\%) \\
\hline Pria & 43 & 43 \\
Wanita & 57 & 57 \\
\hline \multicolumn{2}{l}{ Sumber : Data Primer Yang Diolah (2018) }
\end{tabular}

Tabel 3. Distribusi Responden Berdasar Usia

\begin{tabular}{ccc}
\hline Usia & Frekuensi & Persentase (\%) \\
\hline$<20$ & 1 & 1 \\
$21-30$ & 20 & 20 \\
$31-40$ & 33 & 33 \\
$41-50$ & 35 & 35 \\
$>50$ & 11 & 11 \\
\hline Sumber : Data Primer Yang Diolah (2018)
\end{tabular}

Tabel 4. Distribusi Responden Berdasar Pendidikan Terakhir

\begin{tabular}{ccc}
\hline Tingkat Pendidikan & Frekuensi & Persentase (\%) \\
\hline SD & 11 & 11 \\
SMP & 18 & 18 \\
SMA/SMK & 59 & 59 \\
D3 & 1 & 1 \\
S1 & 11 & 11 \\
\hline
\end{tabular}

Sumber : Data Primer Yang Diolah (2018)

Berdasarkan Gambar 1 diperoleh informasi bahwa mayoritas responden jenis usahanya adalah manufaktur (produksi/membuat barang) yaitu sebanyak 52 orang atau sebesar 52 persen. Jenis usaha berikutnya yaitu jenis usaha menjual barang/dagang yaitu sebesar 39 orang atau 29 persen. Dan yang ketiga adalah jenis usaha jasa sebanyak 9 orang atau sebesar 9 persen.Berdasarkan Gambar 2 dapat diperoleh informasi bahwa mayoritas responden menyatakan bahwa pemanfaatan media daring tidak penting dalam menjalankan usaha mikro yaitu sebesar 42 persen dan hanya 21 persen responden yang menyatakan bahwa dalam menjalankan usaha mikro peran media daring sangatlah penting. 


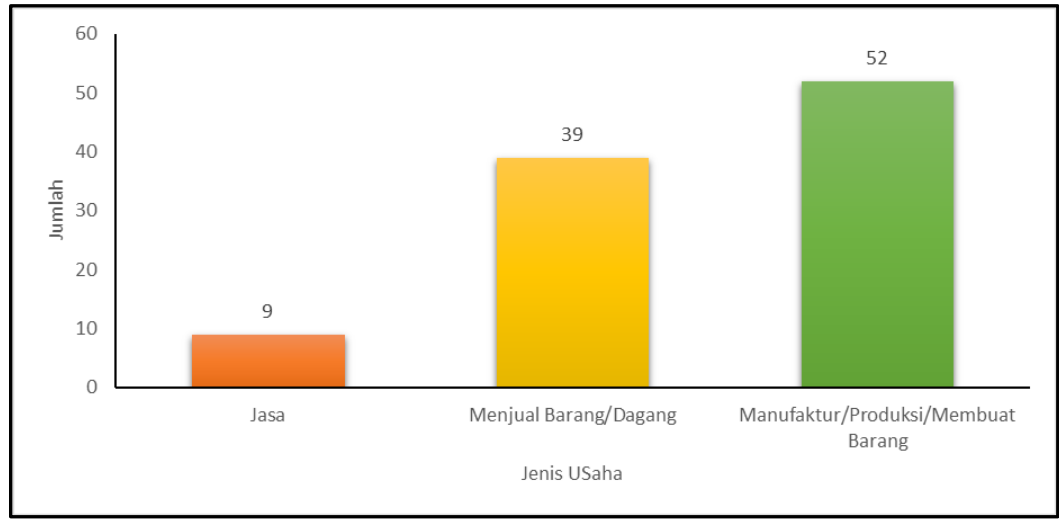

Gambar 1. Jenis Usaha Mikro Yang Dilakukan Responden Sumber : Data Yang Diolah (2018)

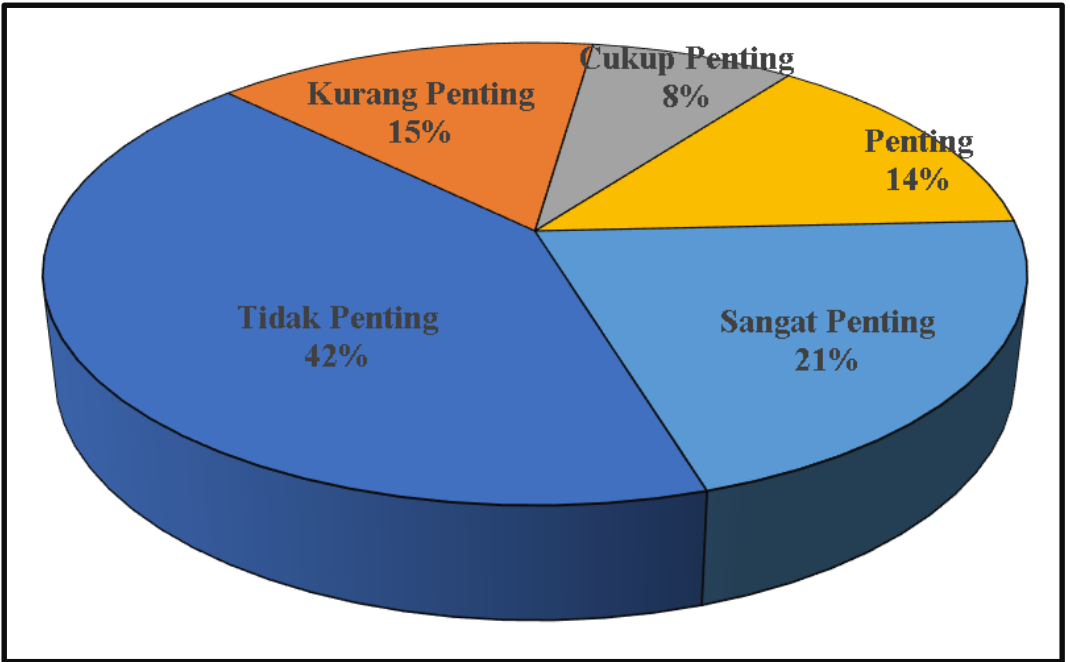

Gambar 2. Persepsi Usaha Mikro Terhadap Penggunaan Media Daring Sumber : Data Yang Diolah (2018)

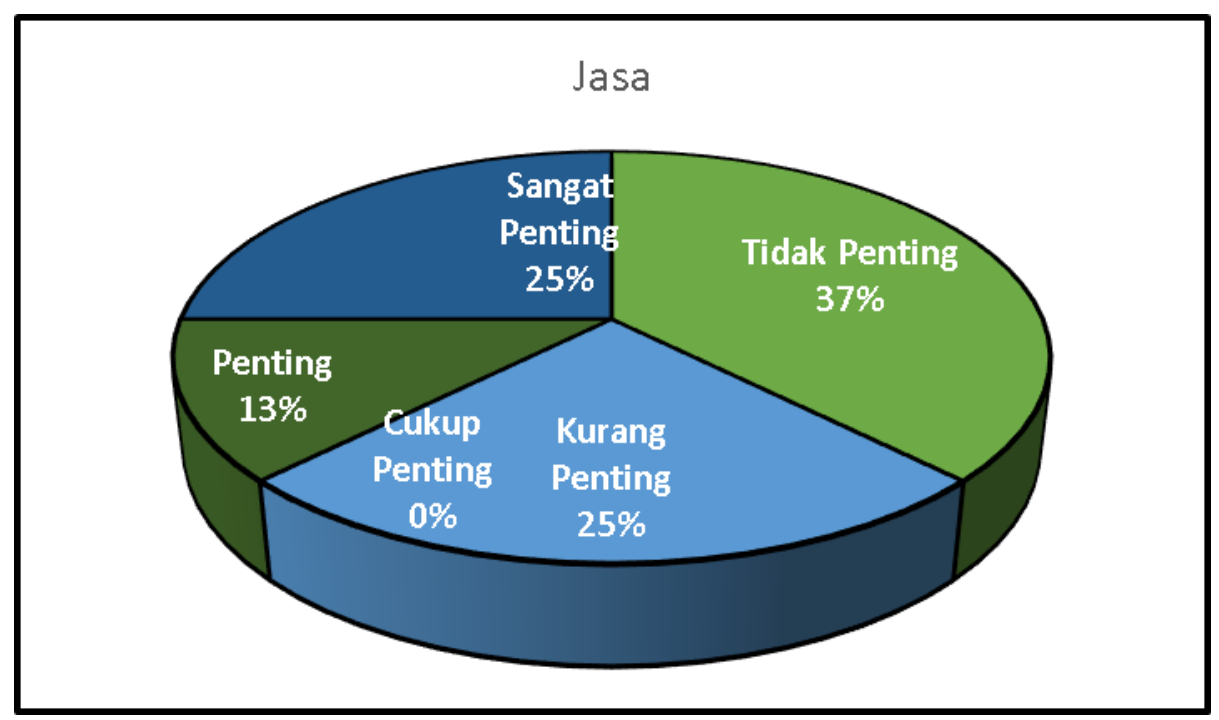

Gambar 3. Persepsi Usaha Mikro Jenis Usaha Jasa Terhadap Penggunaan Media Daring Sumber : Data Yang Diolah (2018) 


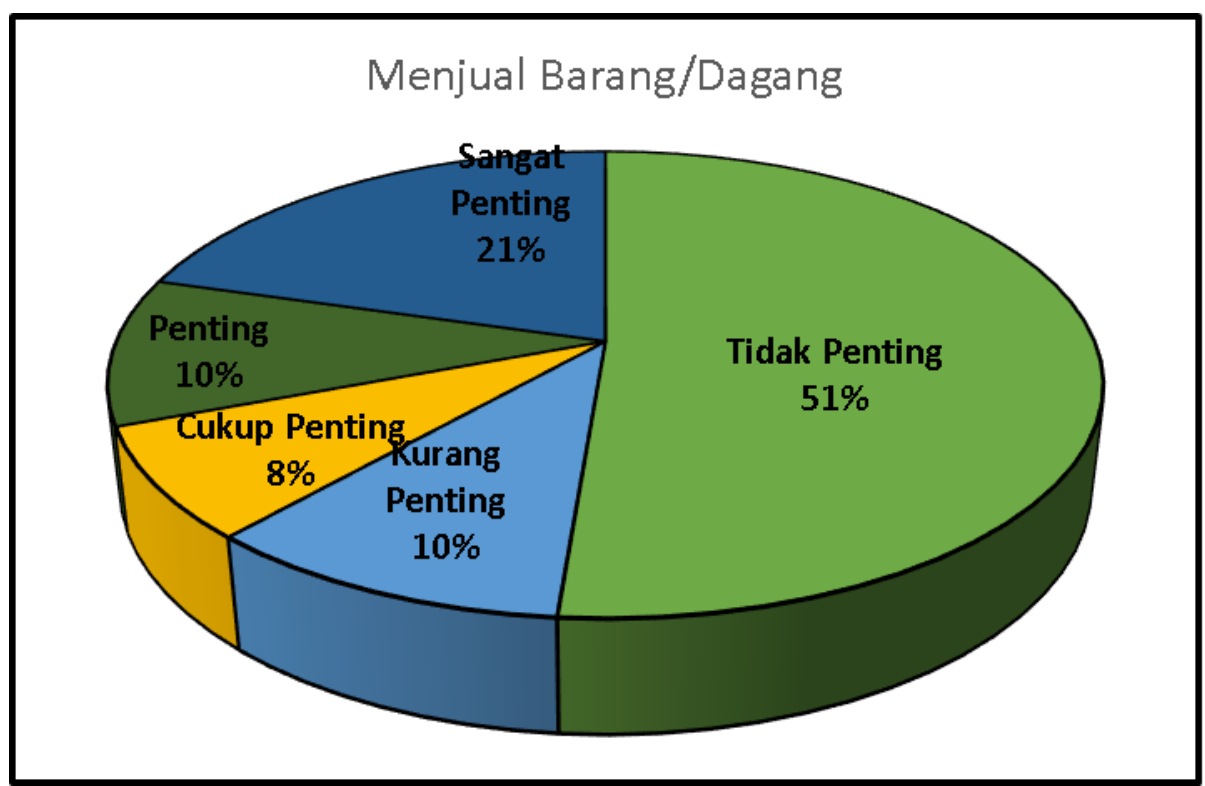

Gambar 4. Persepsi Usaha Mikro Jenis Usaha Menjual Barang/Dagang

Terhadap Penggunaan Media Daring Sumber : Data Yang Diolah (2018)

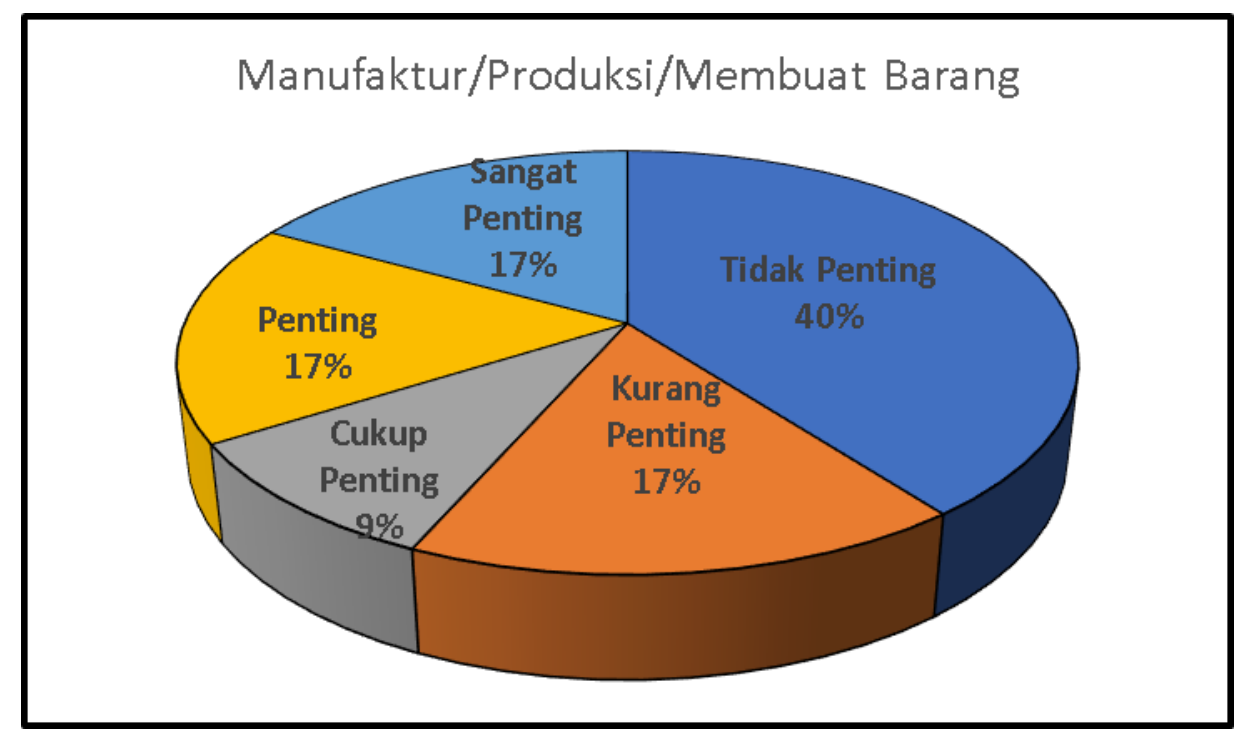

Gambar 5. Persepsi Usaha Mikro Jenis Usaha Manufaktur

Terhadap Penggunaan Media Daring

Sumber : Data Yang Diolah (2018)

Menurut Gambar 3, berdasarkan Jenis Usaha Jasa, 37 persen responden menganggap penggunaan media daring dalam usaha mikro tidak penting, 13 persen menganggap penting dan masing-masing sebesar 25 persen menganggap sangat penting dan kurang penting. Menurut Gambar 4, berdasarkan Jenis Usaha Menjual Barang/Dagang, 51 persen responden menganggap penggunaan media daring dalam usaha mikro tidak penting, 21 persen menganggap sangat penting, 8 persen menganggap cukup penting dan masing-masing sebesar 10 persen menganggap penting dan kurang penting. Menurut Gambar 5, berdasarkan Jenis Usaha Manufaktur/Membuat Barang, 40 persen responden menganggap penggunaan media daring dalam usaha mikro tidak penting, 9 persen menganggap cukup penting, dan masingmasing sebesar 17 persen menganggap penting, kurang penting dan sangat penting. 


\section{Faktor-Faktor Kunci Pemanfaatan Media Daring Dan Strategi Dalam Percepatan Adopsi Penggunaan Media Daring Pada Usaha Mikro}

Berdasarkan analisis terhadap kondisi pemanfaatan media daring pada pelaku Usaha Mikro memperlihatkan bahwa masih terbatasnya akses Usaha Mikro di Kota Samarinda dalam pemanfaatan media daring ini baik dilihat dari penggunaan internet baik komputer maupun handphone dalam pengelolaan usahanya. Terkait dengan hal tersebut, terdapat beberapa faktorfaktor kunci (penghambat dan potensi pendukung) yang menentukan tingkat pemanfaatan media daring pada pelaku Usaha Mikro di Kota Samarinda. Adapun faktor peghambat tersebut antara lain sebagai berikut ini :

\section{Rendahnya pemahaman terhadap manfaat teknologi informasi dalam pengembangan usaha}

Pemahaman pemakai tentang media daring akan menentukan keberhasilan suatu sistem informasi,sebaliknya ketidaktahuan atau kecemasan pemakai terhadap sistem yang baru dapat menyebabkan kegagalan dalam menggunakan media daring. Peningkatan pemahaman pemakai tentang sistem informasi juga berpengaruh terhadap keberhasilan dalam memanfaatkan teknologi. pemilik usaha mikro yang memiliki latar belakang pemasaran, penjualan, Research And Development yang cukup dapat menerima bahwa usaha menerapkan penggunaan teknologi untuk keunggulan kompetitif.

Namun demikian, Usaha Mikro di Kota Samarinda pada umumnya tidak memiliki bagian yang secara khusus mengelola media daring. Umumnya, Usaha Mikro di Kota Samarinda lebih mengandalkan bantuan pihak luar untuk melaksanakan kegiatan yang terkait dengan penggunaan media daring yang berbasis komputer. Ketergantungan dari pihak eksternal akan berkurang manakala para pemilik UKM telah memiliki pemahaman yang cukup terhadap teknologi informasi terutama media daring melalui proses pembelajaran. Dengan tingkat pemahaman teknologi yang tinggi, diharapkan para pemilik Usaha Mikro mengadopsi dan memanfaatkan teknologi informasi terutama media daring secara ekstensif.

\section{Rendahnya Ketersediaan Investasi Teknologi Informasi}

Sebagaimana diketahui, Usaha Mikro pada umumnya memiliki keterbatasan modal dalam menjalankan usaha. Keterbatasan modal ini menyebabkan keraguan pelaku Usaha Mikro dalam menginvestasikan dananya pada media daring, maksudnya adalah investasi baik dari hal perangkat (personal computer atau handphone) dan juga pembelian paket data. baik pada saat ini maupun untuk rencana ke depannya. Hasil penelitian pada Usaha Mikro di Kota Samarinda menunjukkan bahwa persoalan keterbatasan dana bukan menjadi alasan utama mereka tidak menggunakan media daring, tetapi lebih karena faktor keraguan akan kemanfaatan media daring tersebut untuk perkembangan usaha selain itu juga karena faktor lingkup konsumen yang teknologi informasi dak terlalu luas.

\section{Masih Rendahnya Dukungan Lembaga Pemerintah}

Dukungan lembaga pemerintah dalam hal ini adalah mengenai inovasi teknologi. Hal ini telah diakui sebagai faktor pentng dalam aplikasi teknologi informasi seperti media daring. Peran lembaga pemerintah bervariasi mulai dari pemasok informasi tentang inovasi teknologi, penyedia bantuan finansial, pelaksana riset dan pengembangan terpadu. Adanya intervensi pemerintah dalam aplikasi teknologi informasi akan mendorong proses pembelajaran teknologi. Bahkan di beberapa negara, pemerintah menyediakan semacam asisten untuk membantu perusahaan kecil dan menengah dalam menerapkan teknologi informasi ke dalam bisnis mereka.

Diakui bahwa Pemerintah Kota Samarinda melalui Dinas Komunikasi dan Informatika telah memiliki program dan kebijakan (program Smart City) dalam pengembangan teknologi informasi untuk Usaha Mikro di Kota Samarinda yaitu melalui situs samarindamart.id. 
Namun demikian, program-program tersebut belum mampu menyentuh secara secara keseluruhan pada pelaku Usaha Mikro di Kota Samarinda.

Sedangkan potensi pendukung yang menentukan tingkat pemanfaatan media daring pada pelaku Usaha Mikro di Kota Samarinda anatara lain sebagai berikut :

\section{Ketersediaan SDM Dari Sisi Pendidikan yang Relatif Baik}

Dalam peningkatan pemanfaatan media daring pada Usaha Mikro di Kota Samarinda terdapat potensi pendukung, dimana tingkat pendidikan pelaku Usaha Mikro sudah relatif baik yaitu pada tingkat SMA/SMK. Dengan tingkat pendidikan yang baik ini diharapkan akan lebih mempermudah kebijakan dalam memperkenalkan dan mengaplikasikan penggunaan media daring pada Usaha Mikro di Kota Samarinda.

2. Kemampuan Individu Dari Pelaku Usaha Mikro Yang Relatif Baik Dalam Penggunaan Media Daring

Lebih separuh dari pelaku Usaha Mikro yang telah mengunakan media smartphone yang mendukung media daring. Sebagian pelaku Usaha Mikro permasalahannya hanya pada penggunaan paket data dalam pengoperasian media daring.

\section{KESIMPULAN}

Adapun Kesimpulan Kajian Analisis Persepsi Usaha Mikro Terhadap Pemanfaatan Media Daring Di Kota Samarinda adalah (1) Masih terbatasnya pemanfaatan media daring pada pelaku Usaha Mikro baik dilihat dari penggunaan komputer ataupun handphone maupun internet dalam pengelolaan usahanya; (2) Beberapa faktor-faktor kunci penghambat yang menentukan tingkat pemanfaatan media daring pada pelaku Usaha Mikro di Kota Samarinda ini yaitu a) Rendahnya pemahaman terhadap manfaat teknologi informasi terutama media daring dalam pengembangan usaha, b) Rendahnya ketersediaan investasi teknologi informasi, c)Masih rendahnya dukungan lembaga pemerintah. Sedangkan beberapa faktor-faktor kunci pendukung yang menentukan tingkat pemanfaatan teknologi informasi pada pelaku Usaha Mikro di Kota Samarinda ini yaitu (1) Ketersediaan sumberdaya manusia dari sisi pendidikan yang relatif baik; (2) Kemampuan individu dari pelaku usaha mikro yang relatif baik dalam informasi dan teknologi dan dalam pemanfaatan media daring (e-commerce).

\section{REKOMENDASI}

Adapun rekomendasi dari Analisis Persepsi Usaha Mikro Terhadap Pemanfaatan Media Daring Di Kota Samarinda adalah (1) Diperlukan adanya strategi percepatan adopsi penggunaan informasi dan teknologi bagi Usaha MIkro terutama media daring di Kota Samarinda; (2) Strategi percepatan tersebut dapat ditempuh dengan cara (a) Penyediaan infrastruktur teknologi dan informasi yang merata, (b) Penyediaan tenaga ahli di bidang teknologi informasi yang kompeten, (c) Pemberian bantuan teknologi informasi kepada Usaha Mikro, (d) Adanya sosialisasi manfaat informasi dan teknologi dalam pengembangan Usaha Mikro.

\section{DAFTAR PUSTAKA}

Amirin, T. M. (2011). Populasi dan sampel penelitian 4: Ukuran sampel rumus Slovin. Jakarta: Erlangga.

Bao, J dan Sun, X. (2010). A Conceptual Model of Factors Affecting e-Commerce Adoption by SMEs in China, in 2010 Fourth International Conference on Management of e-Commerce and e- Government (ICMeCG), 2010, pp. 172-175. 
Hariati, Ikhsan, \& Nur, D. S. (2018). Pengembangan Usaha Mikro, Kecil Dan Menengah (UMKM) Di Provinsi Kalimantan Timur. Jurnal Paradigma, 7(2), 84-93.

Ningtyas, P. K., Sunarko, B., \& Jaryono. (2015). Analisis Faktor Yang Mempengaruhi Adopsi E-Commerce Dan Pengaruhnya Terhadap Kinerja UMKM. Performance, 21(1), 95-107.

Pangarso, A., Fajar Firdaus, F., \& K. Moeliono, N. (2016). Peran Internet Dalam Saluran Komunikasi Pemasaran Produk UMKM. Jurnal Administrasi Bisnis (JAB), 12(1), 50-62.

Pemerintah Indonesia. (2008). Undang-Undang Nomor 20 Tahun 2008 tentang Usaha Mikro, Kecil dan Menengah. Lembaran Negara Republik Indonesia Tahun 2008 Nomor 93. Jakarta: Sekretariat Negara.

Setiawati, I., Novandalinda, A., \& Prihatiningsih, R. (2017). Pemanfaatan Media Sosial Sebagai Sarana Pemasaran Online Dalam Peningkatan Penjualan Dan Laba Usaha Mikro Kecil Dan Menengah (UMKM). SEGMEN Jurnal Manajemen Dan Bisnis, 13(1), 112.

Setiawati, I., \& Widyartati, P. (2017). Pengaruh Strategi Pemasaran Online terhadap Peningkatan Laba UMKM. In BIMA (Bingkai Manajemen) (pp. 343-347).

Slamet, R., Nainggolan, B., Roessobiyatno, Ramdani, H., Ramdani, H., Hendriyanto, A., \& Ilma, L. lu'ul. (2016). Strategi Pengembangan Ukm Digital Dalam Menghadapi Era Pasar Bebas Development. Jurnal Manajemen Indonesia, 16(2), 136-147.

Turban, T. (2009). Introduction to Electronic Commerce, 2nd ed. New Jersey: Pearson Prentice Hall. 